\title{
Radiofrequency identification (RFID) reveals long-distance flight and homing abilities of the stingless bee Melipona fasciculata
}

\author{
Patrícia Nunes-Silva ${ }^{1}$, Luciano Costa ${ }^{2}$, Alistair John CAMPBell ${ }^{2}$, Helder ArrudA $^{2}$, \\ Felipe Andres Leon ContrerA ${ }^{3}$, Juliana Stephanie Galaschi TeIXEIRA ${ }^{2}$, \\ Rafael Leandro Corrêa Gomes ${ }^{3}$, Gustavo Pessin ${ }^{4}$, Daniel Santiago PereirA ${ }^{5}$, \\ Paulo de SouzA ${ }^{6}$, Vera Lucia IMPERATRIz-FonSECA ${ }^{2}$ \\ ${ }^{1}$ Universidade do Vale do Rio dos Sinos, Av. Unisinos, 950, Cristo Rei, São Leopoldo, Rio Grande do Sul 93020-190, \\ Brazil \\ ${ }^{2}$ Instituto Tecnológico Vale - Desenvolvimento Sustentável, Belém, Pará, Brazil \\ ${ }^{3}$ Instituto de Ciências Biológicas, Universidade Federal do Pará, Belém, Pará, Brazil \\ ${ }^{4}$ Instituto Tecnológico Vale - Mineração, Ouro Preto, Minas Gerais, Brasil \\ ${ }^{5}$ Embrapa Amazônia Oriental, Belém, Pará, Brazil \\ ${ }^{6}$ Data61, CSIRO, Sandy Bay, TAS 7005, Australia
}

Received 30 August 2018 - Revised 30 August 2019 - Accepted 10 October 2019

\begin{abstract}
Determining bee flight capacity is crucial for developing management strategies for bee conservation and/or crop pollination and purposes. In this study, we determined the flight distance of the stingless bee Melipona fasciculata using the radiofrequency identification (RFID) technology. For this, we conducted two translocation experiments using workers equipped with RFID microsensors: (1) release of bees at seven distances between 100 and $3000 \mathrm{~m}$ from experimental colonies in Belém, Brazil, and (2) at six distances between 1500 and 10,000 $\mathrm{m}$ at Carajás National Forest Reserve. Return rates of workers were negatively correlated to release distance, with typical flight distances of $2 \mathrm{~km}$, but a maximum homing distance of $10 \mathrm{~km}$. Use of RFID tags revealed how past experiments may have greatly underestimated homing abilities of stingless bees.
\end{abstract}

flight range / homing / stingless bee / Meliponini / RFID

\section{INTRODUCTION}

The flight distance of bees determines the area they can exploit (Gathmann et al. 1994; WaltherHellwig and Frankl 2000a, b; Wright et al. 2015) and therefore must contain the resources they need

Electronic supplementary material The online version of this article (https://doi.org/10.1007/s13592-019-00706-8) contains supplementary material, which is available to authorized users.

Corresponding author: P. Nunes-Silva, pnsilvabelha@edu.unisinos.br

Manuscript editor Bernd Grünewald to survive and reproduce (e.g., pollen, nectar, nesting habitats, mates). It also influences their ability to migrate and disperse (Aikio 2004; Araújo et al. 2004), with larger bees better equipped to colonize distant habitats (Gathmann et al. 1994), while smaller bees may be at greater risk of extinction/genetic drift, because even small distances between forest fragments could isolate populations (Jaffé et al. 2016). This is particularly pertinent for stingless bees (Apidae, Meliponini), whose mode of dispersal involves an extended process of colony division between the mother and daughter nests and thus can only occur within 
the flight range of workers (Engels and Imperatriz-Fonseca 1990). Therefore, determining flight distance is crucial for understanding bee ecology and also for creating adequate management strategies for bee pollination and/or conservation purposes (Van Nieuwstadt and Iraheta 1996; Gathmann and Tscharntke 2002; Dramstad et al. 2003; Guédot et al. 2009; Wright et al. 2015).

Flight distance in bees is related to their body size (Greenleaf et al. 2007). Particularly for stingless bees, body size, measured by head width (van Nieuwstadt and Iraheta 1996), and other body measurements, including wing sizes (Araújo et al. 2004), are predictors of the flight distance, even within species (Kuhn-Neto et al. 2009). As a group, they present great variation in body size, which implies that individual species likely have different habitat requirements. However, knowledge on the flight range of stingless bees remains limited (Table I). Considering that there are around 500 species of stingless bee in the world (Michener 2013), we found information on the flight range of only 27 species, which corresponds to only $5.4 \%$ (Table I).

Besides size, foraging distance in bees is also related to their homing ability, i.e., ability of individuals to relocate the nest, which occurs through the integration of several systems, e.g., vision, odor, magnetic fields, and memory (Menzel et al. 1998, 2006). Several factors can influence the homing ability of bees, including the presence of landmarks and other distinctive habitat features (Southwick and Buchmann 1995; Leonhardt et al. 2016), pesticide loads (Stanley et al. 2016), diseases ( $\mathrm{Li}$ et al. 2013; Wolf et al. 2014) and pests (Kralj and Fuchs 2006), and experience (Capaldi and Dyer 1999; Rodrigues and Ribeiro 2014). However, most studies are from honey bees (Southwick and Buchmann 1995; Menzel et al. 2006; Pahl et al. 2011; He et al. 2013; Li et al. 2013; Wolf et al. 2014), and temperate bee taxa (Turner 1908; Rau 1929; Goulson and Stout 2001; Guédot et al. 2009; Stanley et al. 2016), and rarely involve non-Apis bees in tropical regions (Rodrigues and Ribeiro 2014; Leonhardt et al. 2016).

Most studies use bee homing ability as a proxy of flight distance, as a common method involving displacing bees from the hive (translocation), rather than actual observations of foraging activities (Janzen 1971; Roubik and Aluja 1983; van Nieuwstadt and Iraheta 1996; Menzel et al. 1998; Gathmann and Tscharntke 2002; Guédot et al. 2009; Rodrigues and Ribeiro 2014; Leonhardt et al. 2016; Campbell et al. 2019). Translocation experiments are time-consuming, because the observer needs to monitor the nest until a marked individual returns, and in the case of social bees, several foragers can return at the same time, meaning it is possible that the observer loses track of marked foragers returning to the hive. These limitations can be overcome by the use of radiofrequency identification (RFID) tracking technology, which monitor hive entrance continuously for a virtually indefinite time period and allow for the precise recording of time taken to return (Streit et al. 2003; Decourtye et al. 2011). In fact, RFID technology has already been applied to study the flight distance and homing ability of Apis mellifera (Pahl et al. 2011) and Bombus terrestris (Stanley et al. 2016), but never in a stingless bee species (Nunes-Silva et al. 2019).

Considering that knowledge on flight distances in stingless bees is limited (Table I) and to this date, the use of RFID tracking technology has not been applied to stingless bees, the main aim of the present study was to estimate the flight distance and homing ability of Melipona fasciculata Smith using RFID technology. The flight distance and homing ability of Amazonian stingless bee species have been studied occasionally in the forest (Roubik and Aluja 1983), which is the case of this study. We expected a decrease in bee return rates with release distance and time taken by individual workers to return to experimental colonies to increase with distance.

\section{MATERIAL AND METHODS}

\subsection{Bee colonies and RFID equipment}

Colonies were housed in wooden hives commonly used to breed this species (Venturieri 2004). At the front of the hives, we attached a plastic box containing the RFID reading equipment (Figure 1). One RFID reader (RU-824, MTI, Inc. Taiwan) and a data logger (Linux Mini 
Table I. List of studies on the flight distance of stingless bees. $G$, genre; $F$, female, worker; $M$, male; $M D$, maximum distance reported; $F T$, ferrous tag glued to bee thorax, which was collected by a magnet at the entrance of the hive; $P M$, paint mark

\begin{tabular}{|c|c|c|c|c|}
\hline Species & G & Method & $\mathrm{MD}(\mathrm{km})$ & Reference \\
\hline Cephalotrigona capitata & $\mathrm{F}$ & Translocation; FT & 1.5 & Roubik and Aluja 1983 \\
\hline Frieseomelitta varia & $\mathrm{F}$ & Linear regression & 1.4 & Araújo et al. 2004 \\
\hline Geotrigona inusitata & $\mathrm{F}$ & Linear regression & 1.2 & \\
\hline Melipona bicolor & $\mathrm{F}$ & Linear regression & 2.3 & \\
\hline Melipona compressipes & $\mathrm{F}$ & Translocation; PM & 2.47 & Kerr 1987 apud Araújo et al. 2004 \\
\hline Melipona fasciata & $\mathrm{F}$ & Translocation; FT & 2.1 & Roubik and Aluja 1983 \\
\hline Melipona fuliginosa & $\mathrm{F}$ & Translocation; PM & 2 & Wille 1976 \\
\hline \multirow[t]{2}{*}{ Melipona mandacaia } & $\mathrm{F}$ & Feeder translocation & 2.1 & Kuhn-Neto et al. 2009 \\
\hline & $\mathrm{F}$ & Translocation; PM & 2.7 & Rodrigues and Ribeiro 2014 \\
\hline Melipona marginata & $\mathrm{F}$ & Not informed & 0.8 & Wille 1983 \\
\hline Melipona quadrifasciata & $\mathrm{F}$ & Translocation; PM & 2 & Kerr 1987 apud Araújo et al. 2004 \\
\hline \multirow[t]{2}{*}{ Melipona scutellaris } & M & Translocation; PM & 1 & Carvalho-Zilse and Kerr 2004 \\
\hline & $\mathrm{F}$ & Linear regression & 2.6 & Araújo et al. 2004 \\
\hline \multirow[t]{2}{*}{ Melipona subnitida } & $\mathrm{F}$ & Feeder translocation & 1.16 & Silva et al. 2014 \\
\hline & $\mathrm{F}$ & Translocation; PM & 4 & \\
\hline \multirow[t]{3}{*}{ Nannotrigona testaceicornis } & $\mathrm{F}$ & Translocation; PM & 0.62 & Nieuwstadt and Iraheta 1996 \\
\hline & $\mathrm{F}$ & Feeder translocation & 0.12 & \\
\hline & $\mathrm{F}$ & Linear regression & 0.9 & Araújo et al. 2004 \\
\hline \multirow[t]{3}{*}{ Partamona aff cupira } & $\mathrm{F}$ & Translocation; PM & 0.8 & Nieuwstadt and Iraheta 1996 \\
\hline & $\mathrm{F}$ & Feeder translocation & 0.52 & \\
\hline & $\mathrm{F}$ & Linear regression & 1.7 & Araújo et al. 2004 \\
\hline Plebeia droryana & $\mathrm{F}$ & Translocation; PM & 0.54 & Kerr 1987 apud Araújo et al. 2004 \\
\hline Plebeia mosquito & $\mathrm{F}$ & Feeder translocation & 0.5 & Kerr 1959 \\
\hline Plebeia poecilochroa & $\mathrm{F}$ & Linear regression & 0.8 & Araújo et al. 2004 \\
\hline \multirow[t]{2}{*}{ Scaptotrigona postica } & $\mathrm{F}$ & Linear regression & 1.7 & Araújo et al. 2004 \\
\hline & $\mathrm{F}$ & Translocation; PM & 0.87 & Campbell et al. 2019 \\
\hline Scaura latitarsis & $\mathrm{F}$ & Linear regression & 0.6 & Araújo et al. 2004 \\
\hline \multirow[t]{3}{*}{ Tetragonisca angustula } & $\mathrm{F}$ & Translocation; PM & 0.83 & \multirow[t]{2}{*}{ Nieuwstadt and Iraheta 1996} \\
\hline & $\mathrm{F}$ & Feeder translocation & 0.32 & \\
\hline & $\mathrm{F}$ & Linear regression & 0.6 & Araújo et al. 2004 \\
\hline Tetragonula carbonaria & $\mathrm{F}$ & Translocation; PM & 0.71 & Smith et al. 2017 \\
\hline \multirow[t]{2}{*}{ Trigona corvina } & $\mathrm{F}$ & Translocation; PM & 0.76 & \multirow[t]{2}{*}{ Nieuwstadt and Iraheta 1996} \\
\hline & $\mathrm{F}$ & Feeder translocation & 0.68 & \\
\hline Trigona hypogea & $\mathrm{F}$ & Linear regression & 1.2 & Araújo et al. 2004 \\
\hline Trigona minangkabau & $\mathrm{F}$ & Feeder translocation & 0.5 & Inoue et al. 1985 \\
\hline Trigona recursa & $\mathrm{F}$ & Linear regression & 1.4 & Araújo et al. 2004 \\
\hline Trigona spinipes & $\mathrm{F}$ & Feeder translocation & 0.84 & Kerr 1959 \\
\hline Trigona trinidadensis & $\mathrm{F}$ & Feeder translocation & 0.98 & Kerr 1959 \\
\hline
\end{tabular}




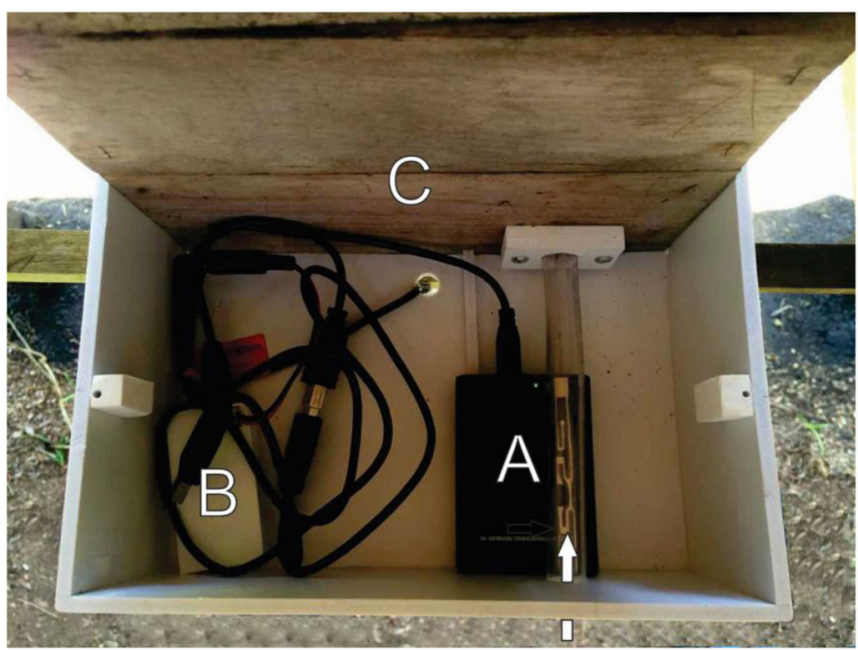

Figure 1. Experimental hive set up. Arrow—bees' entrance. A RFID reader. B Computer (data logger). C Beehive.

Chemical Co. Ltd., Japan) that operate in UHF, from 860 to $920 \mathrm{MHz}$. Each tag measures $2.5 \times$ $2.5 \times 0.3 \mathrm{~mm}$ and weighs $5.4 \mathrm{mg}$.

As can be seen in Figure 1, there is a transparent hose of $10 \mathrm{~cm}$ in the hive entrance. The bees pass through the hose to enter the hive. The RFID reader is below the hose. The reader distance is 3 $\mathrm{cm}$; hence, as the hose is 1 inch wide $(2.54 \mathrm{~cm})$, we do not lose any read due to distance. Also, the reader detects the tag in any position, so it is not necessary to ensure that the bee passes the hose in any determined position.

The reader software was developed by our group. It records the ID number and the time of the event to a database. The algorithm also filters succession registrations at the same reader antenna, which can occur when a labeled bee stands on the reader for a long period. We created an easyto-use interface with Python for selecting the data of interest and performing the data analysis.

\subsection{Bee capture, tagging, and release}

To collect foragers, hive entrances were temporarily blocked and returning bees captured using entomological net or aspirator, starting at 8:30. An RFID tag was subsequently glued (highdensity cyanoacrylate, Tekbond; Figure 2) to the thoraces of captured bees by first placing a small quantity of glue on the thorax using a toothpick and then the tag using tweezers. After the glue dried, individuals were placed in $15-\mathrm{mL}$ falcon tubes, which contained a piece of paper soaked with sugar syrup $(50 \%)$ to standardize energy stores and flight capacity among captured workers. Captured bees were kept in the dark until the transport to the release distance, before the lids of tubes were removed, and bees allowed to fly away. The number of distances evaluated on given day depended on the number of foragers collected and tagged until the release time (11:00). Bees were captured and released on the same day. Distances were tested each day at random.

\subsection{Experiments}

The first experiment (experiment 1) was conducted at Embrapa Amazônia Oriental, Belém, Pará State, Brazil ( $1^{\circ} 26^{\prime} 10.86^{\prime \prime} \mathrm{S} ; 48^{\circ} 26^{\prime}$ 36.05" W; Figure 3) in March and April 2017. This site forms part of the environmental protection area that lies east and south of the metropolitan region of Belém and is composed of a patchwork mosaic of urban land uses, cropland, and secondary and primary rainforest habitats of circa $56.54 \mathrm{~km}^{2}$ (IMAZON 2013). Three colonies of M. fasciculata were used to obtain foragers. To determine the flight distance of $M$. fasciculata, seven distances from experimental colonies were used: 100 m, 600 m, 1100 m, 1600 m, 2100 m, 


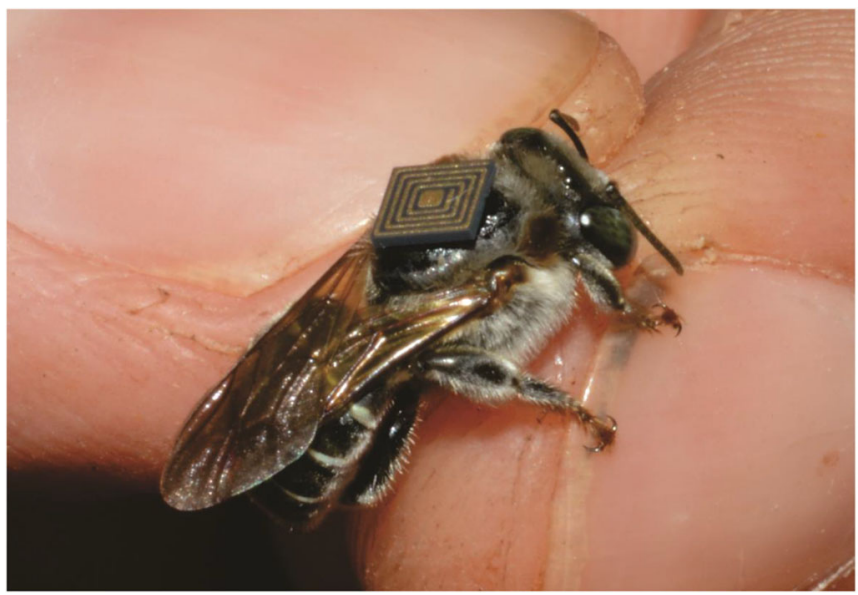

Figure 2. Melipona fasciculata forager, equipped with an RFID transponder.

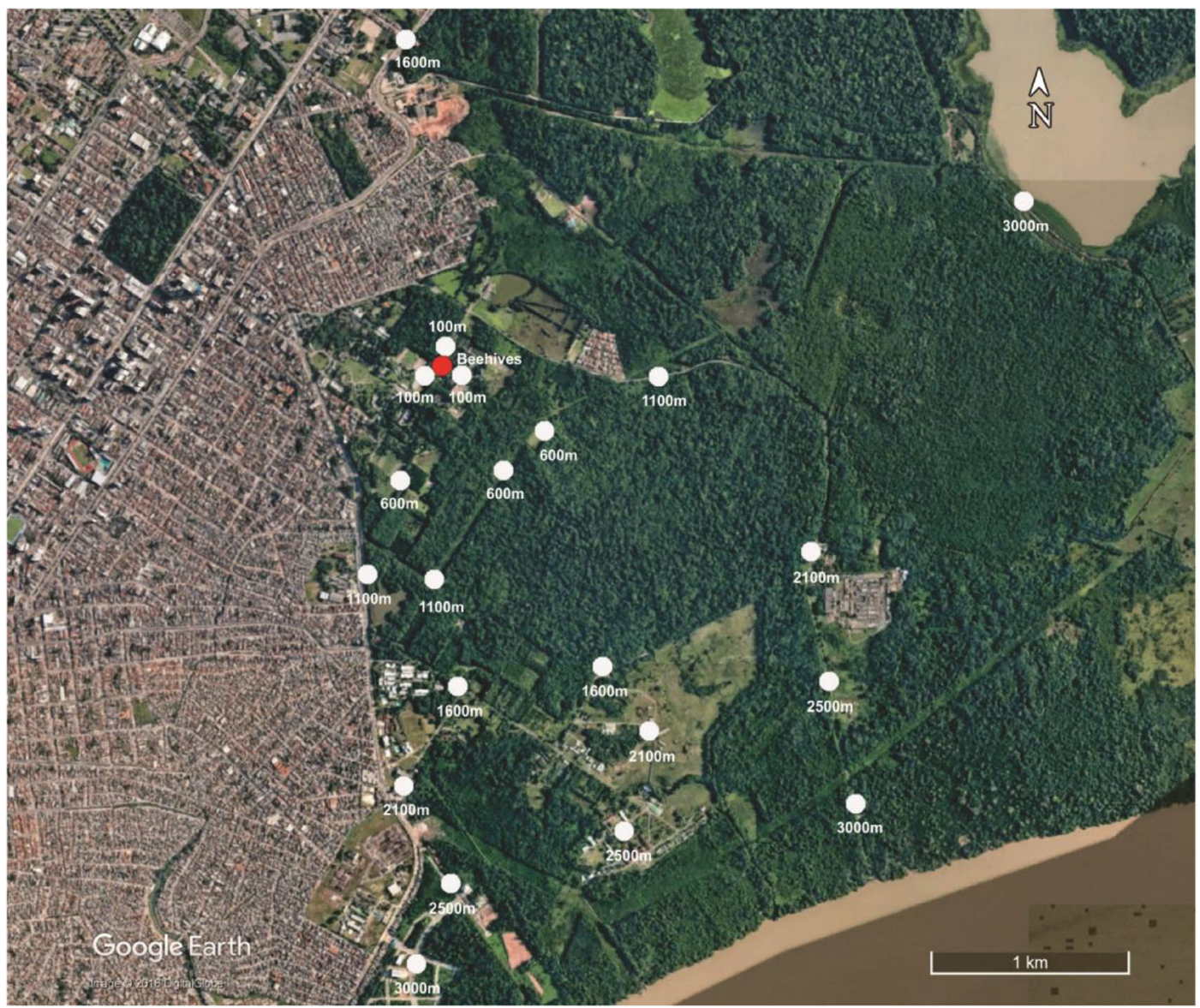

Figure 3. Release points around Embrapa Amazônia Oriental, Belém, Brazil. The red dot is the location of the hives. 
$2500 \mathrm{~m}$, and $3000 \mathrm{~m}$. For each distance, we used three different release points $(\mathrm{A}, \mathrm{B}$, and $\mathrm{C}$; Figure 3). Each day, five foragers from each colony were collected for one of the three release points of the distances tested that day. Overall, five bees per colony were released per point (Figure 3), totaling 15 bees per release point (three colonies), and 45 bees per distance (three replicate points per distance).

The second experiment (experiment 2) was conducted at Carajás National Forest $\left(6^{\circ} 4^{\prime \prime}\right.$ 14,972" S; 50 4" 6886" W; Figure 4), Brazil, encompassing an area of $4113 \mathrm{~km}^{2}$ (MMA and ICMBio 2016). Created in 1998, the purpose of this conservation unit is the environmentally responsible use of mineral resources and scientific research focusing on sustainable resource use (Ministério do Meio Ambiente and ICMBio 2016). It is located in the Amazon biome and presents, predominately, Open Ombrophilous Forest, Ombrophilous Dense Forest, and Amazon Canga savannahs (ferruginous "Campo Rupestre") (MMA and ICMBio 2016). The main economic activity in the area is mining, mainly for iron ore, although copper, manganese, and gold are also mined, among other minerals (MMA and ICMBio 2016).

Experiment 2 took place during July and $\mathrm{Au}-$ gust 2017 and, based on the results from experiment 1 , focused on determining the maximum flight distance of $M$. fasciculata. Thus, the distances $1500 \mathrm{~m}, 3000 \mathrm{~m}, 4000 \mathrm{~m}, 5000 \mathrm{~m}, 7000 \mathrm{~m}$, and 10,000 $\mathrm{m}$ were tested, with all release points located in dense forested habitats (Figure 4). A single colony was used to obtain foragers. Ten to 20 foragers were collected, tagged, and individually stored in 15-mL falcon tubes before being released. Five workers were released per distance (1500 m, $3000 \mathrm{~m}, 4000 \mathrm{~m}, 5000 \mathrm{~m}, 7500 \mathrm{~m}$, and $10,000 \mathrm{~m}$; Figure 4), and each day, two to four distances were tested, depending on the number of foragers collected. In total, 30 bees were released at each distance.

\subsection{Statistical analysis}

To determine flight distance in foragers of $M$. fasciculata, we used the number of released foragers returning ("bee return rates") to the colony and duration of bee return over the full duration of the experiment ( 7 days following the last release), where the increase of duration of return (pointed out by statistical differences between durations) indicated that released foragers were lost and thus unable to relocate colonies based on environmental cues and/or experience from previous foraging trips. Therefore, we assumed that, although variation in flight distance is expected, foraging distance in M. fasciculata is probably similar to the flight distance estimated in our translocation experiments.

All statistical analyses were described below, and graphs were done using Past 3.6 (Hammer et al. 2001) and Microsoft Excel.

\subsubsection{Experiment 1}

There was no significant difference between colonies in the bee return rates (Shapiro-Wilk, hive $1, p=0.64$; hive $2, p=$ 0.69 ; hive $3, p=0.18$; ANOVA, $p=0.93$ ) and the duration of bee return (Shapiro-Wilk, hives 1, 2, and 3, $p<0.001$; Kruskal-Wallis test, $p=0.97)$. Therefore, we pooled data from individual hives to test the difference in bee return rates and time taken to return from different release distances. All bees that returned were included in the analysis, regardless of when.

We used an ANOVA $(\alpha=0.05)$ to test differences in the number of bee returns between release distances (points grouped), because the data followed normal distribution (Shapiro-Wilk, $p>0.05$ ). However, duration of bee returns did not follow a normal distribution (Shapiro-Wilk, $p<0.05$ ), and so a Kruskal-Wallis test $(\alpha=0.05)$ was used to assess differences in the duration of bee return between distances. There was no difference in the duration of bee return between replicates of each release distance (points A, B, and C) (Online Resource 1).

A Spearman correlation test was used ( $\alpha=$ 0.05 ) to test the relationship between release distance, (1) the return rate of foragers, and (2) the duration of return. Data from individual release points were pooled for each distance. 


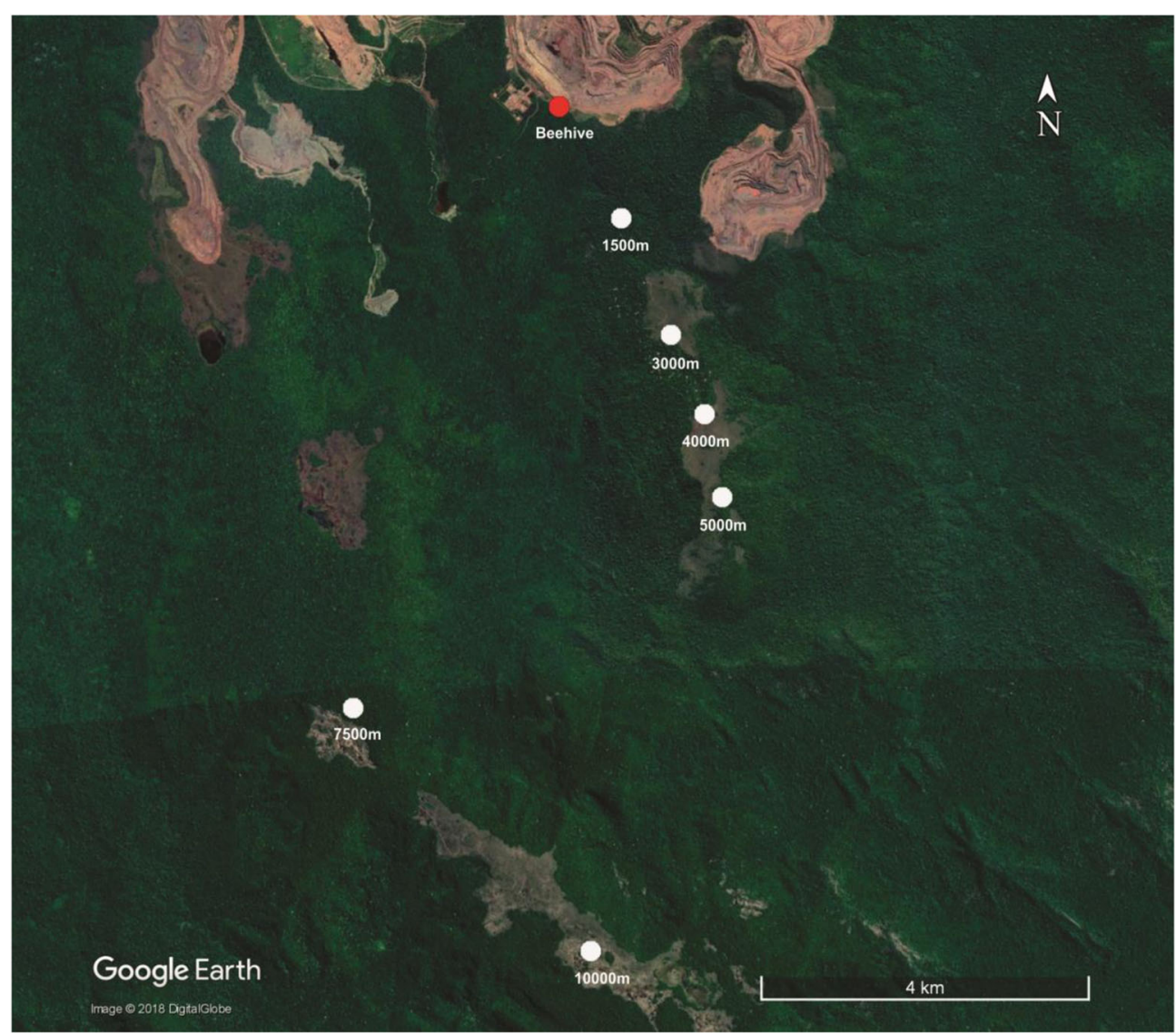

Figure 4. Releasing points at Floresta Nacional de Carajás, Brazil. The red dot is the location of the hives.

\subsubsection{Experiment 2}

Bee return rate was not compared among distances because only a single colony was tested. As duration of bee return did not follow a normal distribution (Shapiro-Wilk, $p<0.05$ ), a KruskalWallis test ( $\alpha=0.05$ ) was used to verify whether the duration of bee return differed among the distances.

\subsection{Comparison between 3 and $24 \mathrm{~h}$ of observation}

We chose to compare bee return rates at 3 and $24 \mathrm{~h}$ following release because we considered that more than $3 \mathrm{~h}$ of direct observation is impractical. The aim of this comparison was to show how time restriction affects return rates and discuss the methods used for estimating flight distance and homing ability.

\section{RESULTS}

\subsection{Flight distance: bee return rates}

In experiment 1 , for all colonies combined and considering all bee returns without restriction on the period of observation, there was a significant difference in return rates among release distances (ANOVA, $p=0.04$; Tukey's pairwise, $p>0.05$ ), with return rates decreasing linearly with distance $(r=-0.72, p<0.05$; Table II). Almost half of the bees came back from the distances up to $2100 \mathrm{~m}$ (Table II). In experiment 2, bee return rate also decreased with distance (Table II). 
Table II. Overview of bee returns in the translocation experiments 1 and 2. \# bees, the number of bees that returned to the hive from 45 that were released; $I Q$, interquartile; Min, minimum duration of bee return; Max, maximum duration of bee return; Minimal flight speed, estimated by diving distance by minimum duration of bee return.

\begin{tabular}{|c|c|c|c|c|c|c|c|c|c|}
\hline \multirow[b]{2}{*}{ Experiment } & \multirow[b]{2}{*}{$\begin{array}{l}\text { Distance } \\
(\mathrm{m})\end{array}$} & \multirow[b]{2}{*}{$\begin{array}{l}\text { Bee return } \\
\text { rates }(\%)\end{array}$} & \multicolumn{3}{|c|}{ Duration of bee returns (min) } & \multirow[b]{2}{*}{$\begin{array}{l}\# \\
\text { bees }\end{array}$} & \multirow[b]{2}{*}{$\begin{array}{l}\operatorname{Min} \\
(\min )\end{array}$} & \multirow[b]{2}{*}{$\begin{array}{l}\operatorname{Max} \\
(\min )\end{array}$} & \multirow[b]{2}{*}{$\begin{array}{l}\text { Minimal flight } \\
\text { speed ( } \mathrm{m} / \mathrm{min})\end{array}$} \\
\hline & & & $\begin{array}{l}\text { Median } \\
(\mathrm{min})\end{array}$ & $\begin{array}{l}\text { IQ1 } \\
(25 \%)\end{array}$ & $\begin{array}{l}\text { IQ3 } \\
(75 \%)\end{array}$ & & & & \\
\hline \multirow[t]{7}{*}{1} & 100 & 80 & 47 & 14 & 115 & 36 & 1 & 1080 & 90.9 \\
\hline & 600 & 71.1 & 68 & 31 & 262 & 32 & 4 & 1255 & 157.9 \\
\hline & 1100 & 62.2 & 49 & 22 & 135 & 28 & 6 & 1411 & 183.3 \\
\hline & 1600 & 48.9 & 120 & 31 & 392 & 22 & 8 & 1468 & 188.2 \\
\hline & 2100 & 48.9 & 141 & 68 & 1383 & 22 & 22 & 1525 & 97.2 \\
\hline & 2500 & 44.4 & 1365 & 103 & 1477 & 20 & 19 & 1935 & 133 \\
\hline & 3000 & 42.2 & 1349 & 131 & 1423 & 19 & 46 & 2837 & 65.5 \\
\hline \multirow[t]{6}{*}{2} & 1500 & 73.3 & 126 & 68.5 & 209.8 & 22 & 11 & 4212 & 140.2 \\
\hline & 3000 & 70 & 1232 & 165.6 & 1685 & 21 & 79 & 4153 & 38 \\
\hline & 4000 & 66.7 & 1267 & 244.5 & 1491.1 & 20 & 93 & 4391 & 42.9 \\
\hline & 5000 & 50 & 1257 & 342.7 & 2687.3 & 15 & 66 & 4083 & 75.5 \\
\hline & 7500 & 26.7 & 1584 & 1490.2 & 2715.3 & 8 & 1374 & 4371 & 5.5 \\
\hline & 10,000 & 3.3 & 3125 & 1562.4 & 2297.8 & 1 & - & - & 3.2 \\
\hline
\end{tabular}

3.2. Flight distance: duration of bee return

\subsubsection{Experiment 1}

The duration of bee return differed among distances (Kruskal-Wallis test, $p<0.05$; Figure 5; Table II) and increased with the distance $(r=$ $0.47 ; p<0.05)$. Bees took significantly longer to return from distances over $2100 \mathrm{~m}$ than individuals released below this distance (Figure 5).

\subsubsection{Experiment 2}

The duration of bee return differed among tested distances (Kruskal-Wallis test, $p<0.05$; Figure 6) and increased with distance from the hive $(r=0.53$; $p<0.05)$. Significant differences in return time were found between $1500 \mathrm{~m}$ and all other distances, and between 3000 and $7500 \mathrm{~m}$ (Figure 6).

\subsection{Comparison between 3 and $24 \mathrm{~h}$ of observation}

When we restricted the number of observed hours to 3 , bee return rates decreased for all distances when compared with $24 \mathrm{~h}$, and this effect was greater for larger distances (Figure 7). For example, in experiment 2 , no bees returned in $3 \mathrm{~h}$ from $7500 \mathrm{~m}$ and 10,000 $\mathrm{m}$ (Figure 7).

\section{DISCUSSION}

In this study, by using RFID technology, we were able to record the astonishing ability of M. fasciculata workers to return to the nest from distances up to $10 \mathrm{~km}$, far greater than previous estimates based on traditional experimental methods and morphometric measures (approx. 2 km: Roubik and Aluja 1983; Wille 1983; Araújo et al. 2004; Greenleaf et al. 2007). Moreover, RFID tags allowed for highly accurate recording of bee return times over much longer time periods $(24 \mathrm{~h})$ than considered possible using traditional observation techniques. When data from $3 \mathrm{~h}$ was compared with uninterrupted $24 \mathrm{~h}$ of observation, it is clear that the homing distance would be greatly underestimated if only visual observation was used, because bees returning from $7500 \mathrm{~m}$ and 10,000 m would not be observed (Figure 7). Furthermore, bee return rates would also be 


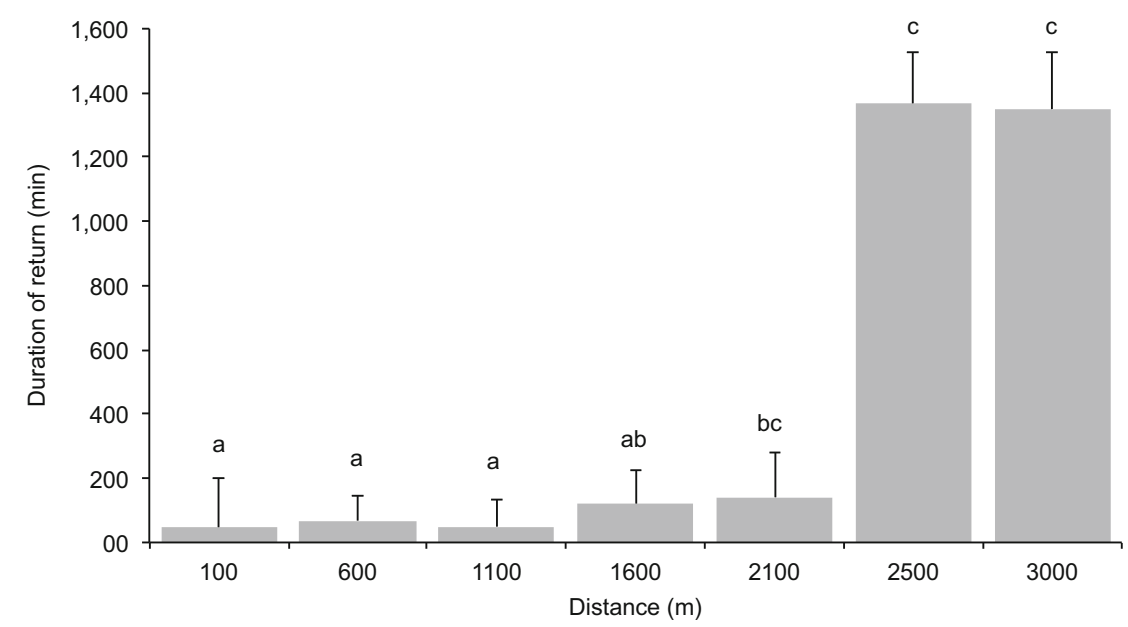

Figure 5. Analyses of the duration of bee return from the distances of release (experiment 1). The results of the translocation experiment done in Embrapa (Belém, Brazil) analyzing all bees that returned to the colonies regardless when they returned. Bars $=$ median. Whiskers: standard error. Different letters indicate statistical difference (Kruskal-Wallis test, $p<0.05$ ).

underestimated (Figure 7). Therefore, spatially explicit models for bee conservation and crop pollination services based on such data may be severely underestimating flight distance and dispersal capacity in stingless bees.

As expected, there was a decrease in bee return rate with release distance and an increase on the duration of return (Table II), as observed for other bee species (Guédot et al. 2009; Rodrigues and Ribeiro 2014; Silva et al. 2014; Smith et al. 2017; Campbell et al. 2019). However, we found great variability in the return time of the foragers (Table II). This variation may be the result of several factors, such as the initiation of foraging on the way back to the nest (Leonhardt et al. 2016), the presence of

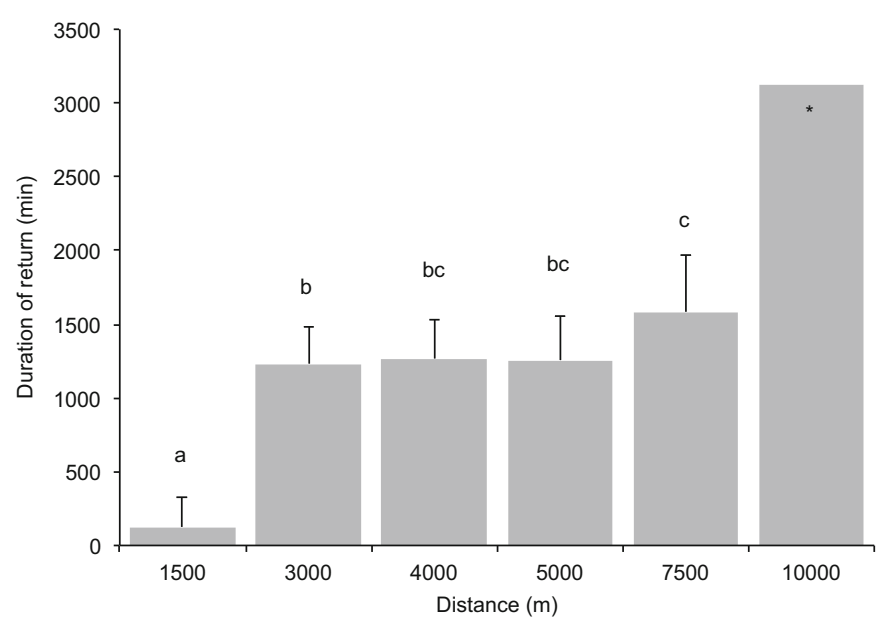

Figure 6. Analyses of the duration of bee return from the distances of release (experiment 2). The results of the translocation experiment done in Carajás (Brazil) analyzing all bees that returned to the colonies regardless when they returned. Bars $=$ median. Whiskers: standard error. Different letters indicate statistical difference (KruskalWallis test, $p<0.05)$. *Not included in the statistical analysis because only one bee returned from $10,000 \mathrm{~m}$. 


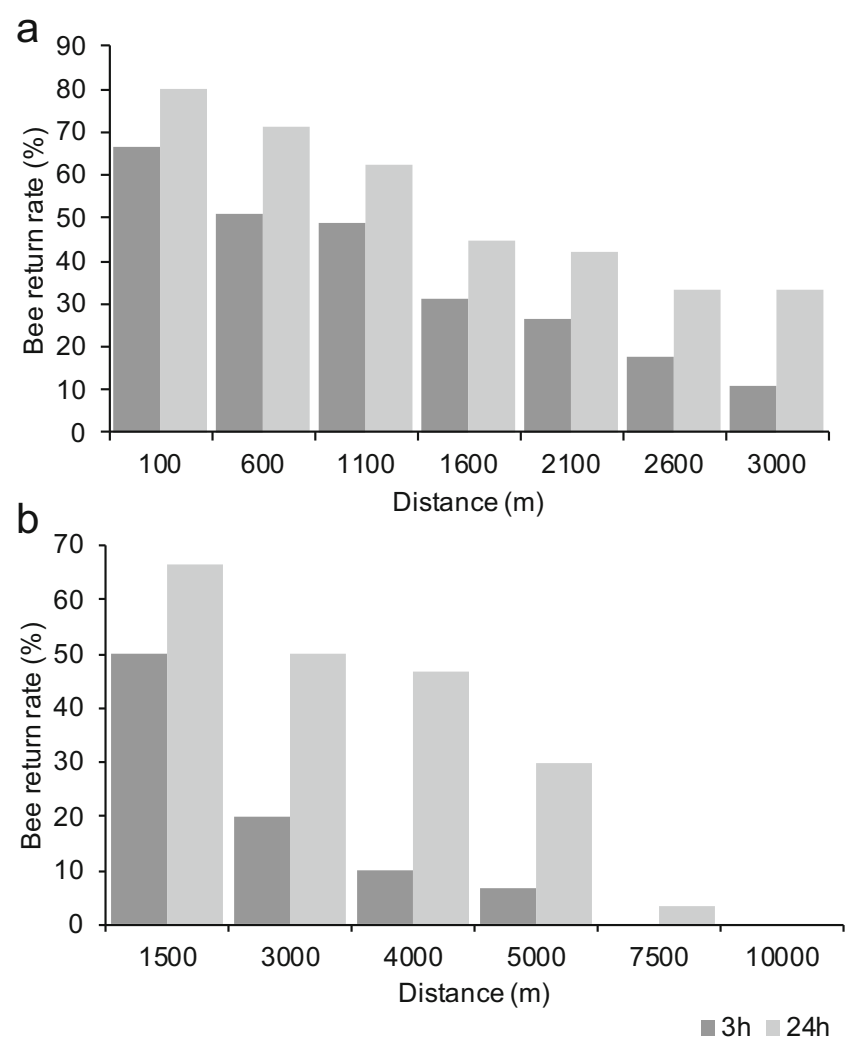

Figure 7. Comparison of the bee return rates between 3 and $24 \mathrm{~h}$ of observation. a Experiment 1. b Experiment 2.

landmarks (Southwick and Buchmann 1995), and forager experience (Capaldi and Dyer 1999; Rodrigues and Ribeiro 2014). From these data, we estimated the flight distance of M. fasciculata to be approximately $2000 \mathrm{~m}$, because, even though foragers frequently returned from greater distances (Table II), the duration of return significantly increased after $2000 \mathrm{~m}$ (Figures 5 and 6), indicating that bees were lost. This corroborates with findings from previous studies that estimated maximum flight distances in Melipona species of similar body size (around $12 \mathrm{~mm}$ ) to be around $2000 \mathrm{~m}$ (Roubik and Aluja 1983; Wille 1983; Araújo et al. 2004). However, even though translocation experiments overestimate flight distances, because foraging implies outbound and inbound flight, not just return (Van Nieuwstadt and Iraheta 1996; Zurbuchen et al. 2010; Silva et al. 2014), smaller homing distances can occur if bees are displaced to an unfamiliar location (van Nieuwstadt and Iraheta 1996; Guédot et al. 2009). Consequently, more studies are needed to evaluate the relationship between the homing ability of Melipona and actual flight distances to determine their foraging range and habitat requirements.

Bee foraging distances are also influenced by spatio-temporal variability in resource availability due to seasonal changes and surrounding landscape structure (SteffanDewenter and Kuhn 2003; Couvillon et al. 2014; Campbell et al. 2019). Accordingly, foraging distances and habitat area are not species-specific traits, and smaller homing distances may be recorded in unfamiliar (i.e., unexploited) habitats (Van Nieuwstadt and Iraheta 1996; Guédot et al. 2009). The only study that investigated influence of surrounding landscape structure on stingless bee 
foraging verified that Tetragonula carbonaria was more successful in returning from homogenous landscapes (forest) than more heterogeneous ones (e.g., gardens; landmarks conspicuous/prominent to the human eye), indicating a complex navigation system that may be similar to one of the honey bees (Leonhardt et al. 2016). This may explain why bee return rates at distances of 1600 and $3000 \mathrm{~m}$ at Embrapa (forest-urban mosaic; Experiment 1) were lower than those from the release points of equivalent distance in Carajás (preserved forest landscape; experiment 2) (Table II). But because the two experiments were done in different months and with different numbers of colonies, further experiments must be done to explore the hypothesis.

In addition, the homing ability of M. fasciculata found here highlights the need for further study into foraging and dispersal ranges of other Melipona species. For example, swarming occurs within the flight range of stingless bees (Engels and Imperatriz-Fonseca 1990); thus, M. fasciculata may be able to swarm up to 7.5 or $10 \mathrm{~km}$ from the nest, if we consider that some foragers were capable of returning from this distances, but the true swarming distance may depend on several other factors, including availability of nesting sites and energetic constraints. This result gives support to a meta-analysis that contradicted the previous belief that, in general, stingless bees have limited gene flow because of body size (Jaffé et al. 2016). It revealed that many stingless bees maintain gene flow across heterogeneous landscapes and body size, an indication of foraging range, did not explain isolation by distance patterns (Jaffé et al. 2016). Our result supports this analysis because it indicates that stingless bees may have greater dispersal distances than previously considered (Van Veen and Sommeijer 2000; Roubik 2006).

Furthermore, instead of concluding that M. fasciculata is capable of exploring an area (habitat size) of 1256 ha, calculated using the estimated foraging distance of 2 $\mathrm{km}$, when we consider the maximum homing distance $(10 \mathrm{~km})$, this area increases to
31,000 ha. It is clear that other factors influence the foraging area and habitat size, but detailed studies of the foraging distance and homing ability are required for the complete understanding of Melipona ecology. Furthermore, the actual foraging range is most likely not circular, but determined by availability of resources within maximum flight range of colonies (Pahl et al. 2011).

That also brings consequences for the use of this bee species as a crop pollinator and their role in wild plant pollination. For crop pollination, being capable of flying long distances makes it harder to efficiently use M. fasciculata to pollinate a target crop, because bees can easily search and use other floral resources other than the crop, similar to what can occur with honey bees (Arnon et al. 2005). On the other hand, foragers from nests located at the edge of large crop fields can easily access the flowers throughout the field, unlike smaller species with more limited flight ranges (Smith et al. 2017). For wild plants, pollinator behavior impacts pollen dispersal and, consequently, functional connectivity (Auffret et al. 2017); thus, flying longer distances may affect these processes and change their role in pollination among plant populations. Based on our results, M. fasciculata, being a generalist flower visitor (Barros et al. 2013; Ribeiro et al. 2016) as other Melipona species (Ferreira and Absy 2018), likely have a key role in maintaining gene flow among isolated populations of wild plants.

In conclusion:

(1) The flight distance of $M$. fasciculata was estimated to be $2 \mathrm{~km}$;

(2) The homing ability of M. fasciculata was $7.5 \mathrm{~km}$, with one case of $10 \mathrm{~km}$, greater than recorded before for the genus;

(3) The use of the RFID technology allowed a greater accuracy of the determination of the homing ability;

(4) Future studies should focus on the influence of the environment on flight distance and homing ability. 


\section{AUTHOR CONTRIBUTIONS}

PNS, LC, AJC, HA, FALC, RLCG, and VLIF conceived this research and designed experiments; PNS, LC, AJC and PS participated in the design and interpretation of the data; PNS, LC, AJC, HA, FALC, JSGT, RLCG, GP, and DSP performed experiments and analysis; PNS, LC, AJC, FALC, RLCG, PS, and VLIF wrote the paper and participated in the revisions of it. All authors read and approved the final manuscript.Funding information

This work was supported by Gerência Executiva de Meio Ambiente and Gerência de Meio Ambiente Ferrosos Norte. AJC was funded by a grant from CAPES/EMBRAPA (15/2014), RLCG by a grant from the Coordenação de Aperfeiçoamento de Pessoal de Nível SuperiorBrasil (CAPES), and PNS and JSGT by grants from Conselho Nacional de Desenvolvimento $\mathrm{Ci}$ entífico e Tecnológico (CNPq).

\section{COMPLIANCE WITH ETHICAL STANDARDS}

Conflict of interest The authors declare that they have no conflict of interest.

\section{OPEN ACCESS}

This article is licensed under a Creative Commons Attribution 4.0 International License, which permits use, sharing, adaptation, distribution and reproduction in any medium or format, as long as you give appropriate credit to the original author(s) and the source, provide a link to the Creative Commons licence, and indicate if changes were made. The images or other third party material in this article are included in the article's Creative Commons licence, unless indicated otherwise in a credit line to the material. If material is not included in the article's Creative Commons licence and your intended use is not permitted by statutory regulation or exceeds the permitted use, you will need to obtain permission directly from the copyright holder. To view a copy of this licence, visit http://creativecommons.org/ licenses/by/4.0/.

L'identification par radiofréquence (RFID) révèle les capacités de vol longue distance et de repérage de l'abeille sans aiguillon Melipona fasciculate.
Distance de vol / retour au nid / abeille sans dard / Meliponini / RFID.

Der Nachweis mittels Radiofrequenzidentifizierung (RFID) von Langdistanzflügen und der Heimfindungsfähigkeit bei der Stachellosen Biene Melipona fasciculate.

Flugbereich / Heimfindung / Stachellose Biene / Meliponini / RFID.

\section{REFERENCES}

Aikio, S. (2004) Competitive asymmetry, foraging area size and coexistence of annuals. Oikos 104, 51-58

Araújo, E.D., Costa, M., Chaud-Netto, J., Fowler, H.G. (2004) Body size and flight distance in stingless bees (Hymenoptera: Meliponini): inference of flight range and possible ecological implications. Braz. J. Biol. 64, 563-568

Arnon, D., Stern, R.A., Shafir, S. (2005) Honey bee (Apis mellifera) strains differ in apple (Malus domestica) pollen. J. Apic. Res. 44, 15-20

Auffret, A.G., Rico, Y., Bullock, J.M., Hooftman, D.A.P., Pakeman, R.J., Soons, M.B., Suárez-Esteban, A., Traveset, A., Wagner, H.H., Cousins, S.A.O. (2017) Plant functional connectivity - integrating landscape structure and effective dispersal. J. Ecol. 105, 16481656

Barros, M.H.M.R., Luz, C.F.P., Albuquerque, P.M.C. (2013) Pollen analysis of geopropolis of Melipona (Melikerria) fasciculata Smith, 1854 (Meliponini, Apidae, Hymenoptera) in areas of Restinga, Cerrado and flooded fields in the state of Maranhão, Brazil. Grana 52, 81-92

Campbell, A.J., Gomes, R.L.C., da Silva, K.C., Contrera, F.A.L. Apidologie (2019). https://doi.org/10.1007 /s13592-019-00682-z

Capaldi, E.A., Dyer, F.C. (1999) The role of orientation flights on homing performance in honeybees. J. Exp. Biol. 202 , 1655-1666

Carvalho-Zilse, G.A., Kerr, W.E. (2004) Substituição natural de rainhas fisogástricas e distância de vôo dos machos em Tiuba (Melipona compressipes fasciculata Smith, 1854) e Uruçu (Melipona scutellaris Latreille, 1811) (Apidae, Meliponini). Acta Amaz 34, 649-652

Couvillon, M.J., Schürch, R., Ratnieks, F.L.W. (2014) Waggle dance distances as integrative indicators of seasonal foraging challenges. PLoS ONE, 9, e93495

Decourtye, A., Devillers, J., Aupinel, P., Brun, F., Bagnis, C., Fourrier, J., Gauthier, M. (2011) Honeybee tracking with microchips: a new methodology to measure the effects of pesticides. Ecotoxicology 20, 429-437 
Dramstad, W.E., Fry, G.L.A., Schaffer, M.J. (2003) Bumblebee foraging-is closer really better? Agric. Ecosyst. Environ. 95, 349-357.

Engels, W., Imperatriz-Fonseca, V.L. (1990) Caste development, reproductive strategies, and control of fertility in honey bees and stingless bees, in: Engels W. (eds) Social Insects. Springer, Berlin, pp. 167-230

Ferreira, M.G., Absy, M.L. (2018) Pollen niche of Melipona (Melikerria) interrupta (Apidae: Meliponini) bred in a meliponary in a terra-firme forest in the central Amazon. Palynology 42, 199-209

Gathmann, A., Tscharntke, T. (2002) Foraging ranges of solitary bees. J. Anim. Ecol. 71, 757-764

Gathmann, A., Greiler, H.J., Tscharntke, T. (1994) Trapnesting bees and wasps colonizing set-aside fields: succession and body size, management by cutting and sowing. Oecologia 98, 8-14

Goulson, D., Stout, J.C. (2001) Homing ability of the bumblebee Bombus terrestris (Hymenoptera: Apidae) Apidologie 32 , 105-111

Greenleaf, S.S., Williams, N.M., Winfree, R., Kremen, C. (2007) Bee foraging ranges and their relationship to body size. Oecologia 153, 589-596

Guédot, C., Bosch, J., Kemp, W.P. (2009) Relationship between body size and homing ability in the genus Osmia (Hymenoptera; Megachilidae). Ecol. Entomol. 34, 158-161

Hammer, Ø., Harper, D.A.T., Ryan, P.D. (2001) PAST: Paleontological statistics software package for education and data analysis. Palaeontol. Electron. 4(1), 1-9

He, X., Wang, W., Qin, Q., Zeng, Z., Zhang, S., Barron, A.B. (2013) Assessment of flight activity and homing ability in Asian and European honey bee species, Apis cerana and Apis mellifera, measured with radio frequency tags. Apidologie 44, 38-51

IMAZON (2013) Plano de Manejo do Parque Estadual do Utinga. Secretaria do Meio Ambiente, Belém

Inoue, T., Salmah, S., Abbas, I., Yusuf, E. (1985) Foraging behavior of individual workers and foraging dynamics of colonies of three Sumatran stingless bees. Res. Popul. Ecol. 27, 373-392

Jaffé, R., Pope, N., Acosta, A.L., Alves, D.A., Arias, M.C., et al. (2016) Beekeeping practices and geographic distance, not land use, drive gene flow across tropical bees. Mol. Ecol. 25, 5345-5358

Janzen, D.H. (1971) Euglossine bees as long-distance pollinators of tropical plants. Science 171, 203-20

Kerr, W.E. (1959) Biology of meliponids VI Aspects of food gathering and processing in some stingless bees, in: Food Gathering Behavior of Hymenoptera. Symp. Entomol. Soc. Am., Detroit, pp. 24-31

Kralj, J., Fuchs, S. (2006) Parasitic Varroa destructor mites influence flight duration and homing ability of infested Apis mellifera foragers. Apidologie 37, 577-587

Kuhn-Neto, B., Contrera, F.A.L., Castro, M.S., Nieh, J.C. (2009) Long distance foraging and recruitment by a stingless bee, Melipona mandacaia. Apidologie 40, $472-480$
Leonhardt, S.D., Kaluza, B.F., Wallace, H. , Heard, T.A. (2016) Resources or landmarks: which factors drive homing success in Tetragonula carbonaria foraging in natural and disturbed landscapes? J. Comp. Physiol. A. $202,701-708$

Li, Z., Chen, Y., Zhang, S., Chen, S., Li, W., Yan, L., Shi, L., Wu, L., Sohr, A., Su, S. (2013) Viral infection affects sucrose responsiveness and homing ability of forager honey bees, Apis mellifera L. PLoS One 8, e77354

Menzel, R., Geiger, K., Joerges, J., Müller, U., Chittka, L. (1998) Bees travel novel homeward routes by integrating separately acquired vector memories. Anim. Behav. 55, 139-152

Menzel, R., De Marco, R.J., Greggers, U. (2006) Spatial memory, navigation and dance behaviour in Apis mellifera. J. Comp. Physiol. A. 192, 889-903

Michener, C.D. (2013) The Meliponini. In: Vit, P., Pedro, S.R.M., Roubik, D.W. (eds.) Pot-honey: a legacy of stingless bees, pp. 3-18. Springer, New York

Ministério do Meio Ambiente (MMA), ICMBio. (2016) Plano de Manejo-Floresta Nacional de Carajás [online] h t t p : / / w w w. i c m b i o.g o v. br/portal/images/stories/biodiversidade/UCRPPN/DCOM_ICMBio_plano_de_manejo_Flona Carajas_volume-_I.pdf (accessed on $\overline{3} 0$ August 18)

Nunes-Silva, P., Hrncir, M., Guimarães, J.T.F., Arruda, H., Costa, L., Pessin, G., Siqueira, J.O., de Souza, P., Imperatriz-Fonseca, V.L. (2019) Applications of RFID technology on the study of bees. Insect. Soc. 66, 1524

Pahl, M., Zhu, H., Tautz, J., Zhang, S. (2011) Large scale homing in honeybees. PLoS One 6, 1-7

Rau, P. (1929) Experimental studies in the homing of carpenter and mining bees. J. Comp. Psychol. 9, 3570

Ribeiro, M.H.M., Albuquerque, P.M.C., Luz, C.F.P. (2016) Pollen profile of Geopropolis samples collected of "Tiúba" (Melipona (Melikerria) fasciculata Smith 1854) in areas of Cerrado and flooded fields in the state of Maranhão, Brazil, Braz. J. Bot. 39 , 895-912

Rodrigues, F., Ribeiro, M.F. (2014) Influence of experience on homing ability of foragers of Melipona mandacaia Smith (Hymenoptera: Apidae: Meliponini). Sociobiology $61,523-528$

Roubik, D.W. (2006) Stingless bee nesting biology. Apidologie 37, 124-143

Roubik, D.W. , Aluja, M. (1983) Flight ranges of Melipona and Trigona in tropical forest. J. Kansas Entomol. Soc. 56, 217-222

Silva, A.G., Pinto, R.S., Contrera, F.A.L., Albuquerque, P.M.C., Rêgo, M.M.C. (2014) Foraging distance of Melipona subnitida Ducke (Hymenoptera: Apidae). Sociobiology 61, 494-501

Smith, J.P., Heard, T.A., Beekman, M., Gloag, R. (2017) Flight range of the Australian stingless bee Tetragonula carbonaria (Hymenoptera: Apidae). Austral Entomol. 56, 50-53 
Southwick, E.E., Buchmann, S.L. (1995) Effects of horizon landmarks on homing success in honey bees. Am. Nat. 146, 748-764

Stanley, D.A., Russell, A.L., Morrison, S.J., Rogers, C., Raine, N.E. (2016) Investigating the impacts of fieldrealistic exposure to a neonicotinoid pesticide on bumblebee foraging, homing ability and colony growth. J. Appl. Ecol. 53 , 1440-1449

Steffan-Dewenter, I., Kuhn, A. (2003) Honeybee foraging in differentially structured landscapes. Proc. R. Soc. B, 270, 569-575

Streit, S., Bock, F., Pirk, C.W.W., Tautz, J. (2003) Automatic life-long monitoring of individual insect behaviour now possible. Zoology 106, 169-171

Turner, C.H. (1908) Biological bulletin the homing of the burrowing-bees (Anthophoridae). Biol. Bull. 15, 247 258

Van Nieuwstadt, M., Iraheta, C. (1996) Relation between size and foraging range in stingless bees (Apidae, Meliponinae). Apidologie 27, 219-228 https://doi. org/10.1051/apido:19960404

Van Veen, J.W., Sommeijer, M.J. (2000) Colony reproduction in Tetragonisca angustula (Apidae, Meliponini). Insect. Soc. 47, 70-75

Venturieri, G. (2004) Meliponicultura I: Caixa Racional de Criação. Comunicado Técnico-Embrapa 123, 1-3

Walther-Hellwig, K., Frankl, R. (2000a) Foraging habitats and foraging distances of bumblebees, Bombus spp.
(Hym., Apidae), in an agricultural landscape. J. Appl. Entomol. 124, 299-306

Walther-Hellwig, K., Frankl, R. (2000b) Foraging distances of Bombus muscorum, Bombus lapidarius, and Bombus terrestris (Hymenoptera, Apidae). J. Insect Behav. 13, 239-246

Wille, A. (1976) Las abjeas jicotes del género Melipona (Apidae: Meliponini) de Costa Rica. Rev. Biol. Trop . 24, 123-147

Wille, A. (1983) Biology of the Stingless Bees. Annu. Rev. Entomol. 28, 41-64

Wolf, S., McMahon, D.P., Lim, K.S., Pull, C.D., Clark, S.J., Paxton, R.J., Osborne, J.L. (2014). So near and yet so far: harmonic radar reveals reduced homing ability of Nosema infected honeybees. PLoS One 9, e103989.

Wright, I.R., Roberts, S.P.M., Collins, B.E. (2015) Evidence of forage distance limitations for small bees (Hymenoptera: Apidae). Eur. J. Entomol. 112, 303310

Zurbuchen, A., Landert, L., Klaiber, J., Müller, A., Hein, S., Dorn, S. (2010) Maximum foraging ranges in solitary bees: only few individuals have the capability to cover long foraging distances. Biol. Conserv. 143, 669-676

Publisher's note Springer Nature remains neutral with regard to jurisdictional claims in published maps and institutional affiliations. 